\section{Effect of Replacing a Component of a Self-Etch Adhesive by Chlorhexidine on Bonding to Dentin}

César Pomacóndor-Hernández', Alberto Nogueira de Gama Antunes², Vinicius di Hipólito ${ }^{3}$, Mário Fernando de Goes ${ }^{1}$

\author{
'Department of Restorative \\ Dentistry, Dental Materials \\ Division, Piracicaba School of \\ Dentistry, UNICAMP - University of \\ Campinas, Piracicaba, SP, Brazil \\ ${ }^{2}$ Department of Restorative \\ Dentistry, Dental School, UNINCOR \\ - Vale do Rio Verde University, \\ Belo Horizonte, MG, Brazil \\ ${ }^{3}$ Biomaterials Research Group, \\ Dental School, ANHANGUERA- \\ UNIBAN - Bandeirante University of \\ São Paulo, São Paulo, SP, Brazil
}

Correspondence: Prof. Dr. Mário Fernando de Goes, Avenida Limeira, 901, Areião, 13414-903 Piracicaba, SP, Brasil. Tel.: +55-19-2106-5346. e-mail: degoes@fop.unicamp.br

\section{Introduction}

Degradation phenomena occur within resin-dentin interface in vitro and in vivo $(1,2)$. Water sorption, solubility and hydrolysis can affect the resin component, causing a decrease of mechanical properties $(3,4)$. In addition, poorly infiltrated collagen fibrils can be degraded by endogenous enzymes, such as matrix metalloproteinases (MMPs) $(1,2)$.

In the etch-and-rinse approach, etched dentin is not fully infiltrated by the adhesive monomers, thereby creating a zone of exposed collagen fibrils that is susceptible to enzymatic degradation $(1,2,5)$. The use of $2 \%$ chlorhexidine digluconate ( $\mathrm{CHX}$ ) as a therapeutic primer prior to the resin monomers' infiltration has been reported to stabilize the resin-dentin bonding due to the inhibition of the MMPs' activity $(1,2,6)$.

On the other hand, the demineralization/infiltration process is simultaneous in the self-etching approach (7). The self-etch adhesives (SEAs) are basically composed of acidic monomers, methacrylate co-monomers, and solvents (8). Water is indispensable for ionizing the acidic monomers, allowing the formation of hydronium ions $\left(\mathrm{H}_{3} \mathrm{O}^{+}\right)$, which is essential for this bonding strategy (7). Nevertheless, nanoleakage tests demonstrated that SEAs also produce resin-dentin bonds with permeable zones, in which collagen fibrils remain exposed, thus creating favorable conditions for enzymatic degradation $(9,10)$.

According to the number of operative steps for bonding, SEAs can be classified in two-step adhesives, in which primer and adhesive are individually applied, and onestep adhesives, which consist of a single primer/adhesive application step (7). In the composition of one-step SEAs and in the primer solution of two-step SEAs, blends of water and acidic monomers may produce acidified solutions due to the ionization of functional groups prior to the adhesive application. This condition can gradually activate the hydrolysis of the ester portion of the methacrylated monomers, leading to a decrease in monomer concentration over time, as well as reducing the shelf life of the adhesive (11). In order to minimize this drawback, an innovative onestep SEA was introduced, represented by Adper Scotchbond SE (3M ESPE, St. Paul, MN, USA). Liquid A of this adhesive, which is basically composed by water, is mixed with the acidic monomers and co-monomers of the liquid $B$ just at the moment of hybridization on the dental tissue, thereby avoiding acid-catalyzed hydrolysis of methacrylated monomers prior to the application of the adhesive.

As little is known about the influence of $\mathrm{CHX}$ on dentin bonding performance using SEAs, the purpose of the present 
study was to evaluate the effect of replacing liquid $A$ of Adper Scotchbond SE by a 2\% CHX aqueous solution on bonding to dentin. The research hypotheses were that 1) the immediate bond strength is not affected and 2) the bond strength after 3 and 6 months is preserved.

\section{Material and Methods}

\section{Tooth Preparation}

Eight carious-free human third molars were obtained and used in accordance with the guidelines presented by the local Institutional Review Board (\#144/2009). Occlusal enamel and roots were severed to expose a flat dentin surface. Each tooth was then longitudinally sectioned into halves and assigned to one of two groups - the control or the experimental group. Prior to the bonding procedures, dentin surfaces were wet ground with \#600-grit silicon carbide paper to standardize a smear layer (12).

\section{Bonding Procedures}

The one-step SEA Adper Scotchbond SE was used. Its composition and application mode are presented in Table incrementally built on the bonded surfaces, with each 2 mm-thick increment being light cured for $20 \mathrm{~s}$ using an LED curing unit (Elipar Freelight 2; 3M ESPE) operating at $900 \mathrm{~mW} / \mathrm{cm}^{2}$. Restored half-teeth were then stored in distilled water for $24 \mathrm{~h}$ at $37^{\circ} \mathrm{C}$.

\section{Microtensile Bond Strength Testing}

The samples were sectioned longitudinally in both " $x$ " and " $y$ " directions across the bonded interface using a diamond wafering blade (Buehler Ltd., Lake Bluff, IL, USA) at low-speed mounted in precision cutting machine (IsoMet 1000; Buehler Ltd.) with water cooling. A series of $0.8 \mathrm{~mm}^{2}$
$( \pm 0.2)$ stick-shaped specimens were produced. Eight to ten sticks were obtained from each hemi-block and were randomly assigned to three sub-groups according to storage time: 1 day, 3 months, or 6 months. Each specimen was tested in tension at a crosshead speed of $0.5 \mathrm{~mm} / \mathrm{min}$ until failure in an Instron 4411 machine (Instron Corporation, Canton, MA, USA).

\section{Statistical Analysis}

A bond strength mean value was obtained for each level evaluated in each tooth. As all levels of both main factors (C vs. CHX [treatment], and 1 day vs. 3 months vs. 6 months [storage time]) were analyzed for each tooth, bond strength values were subjected to two-way repeated measures ANOVA at a pre-set alpha of 0.05 . The repeated measures were treatment and storage time, and the experimental unit $(n=8)$ was the teeth.

\section{Failure Mode Classification}

All fractured surfaces were sputter-coated with gold/ palladium (SCD050 Sputter Coater; Bal-Tec AG, Balzers, Liechtenstein) and analyzed with a scanning electron microscope (JSM-5600LV; Jeol Ltd., Tokyo, Japan) operating at $15 \mathrm{kV}$. Failure modes were classified according to the following categories: Type I - Cohesive failure within the resin composite; Type II - Cohesive failure within the adhesive resin; Type III - Mixed failure: cohesive within the adhesive resin and resin composite; Type IV - Mixed failure: cohesive within the hybrid layer and adhesive resin; and Type V - Cohesive failure within the hybrid layer.

\section{Bonding Interface Analysis}

Four teeth were selected and distributed into two groups (the control and the experimental group). Each tooth was sectioned to obtain two $1.5 \pm 0.5 \mathrm{~mm}$-thick dentin discs. The adjacent dentin surfaces of the discs were subjected to the treatment described above, and then laminated

Table 1. Composition of the adhesive

\begin{tabular}{|c|c|}
\hline Composition* and batch number & Application mode \\
\hline & $\begin{array}{l}\text { 1) Dispense } 1 \text { drop of liquid } A \text { into one of the dispensing wells } \\
\text { and } 1 \text { drop of liquid } B \text { into the second dispensing well. }\end{array}$ \\
\hline Liquid A: water, HEMA & $\begin{array}{l}\text { 2) Apply the liquid } A \text { to the entire bonding area to } \\
\text { obtain a continuous red-colored layer. }\end{array}$ \\
\hline $\begin{array}{l}\text { Liquid B: surface treated zirconia, TEGDMA, di- } \\
\text { HEMA phosphates, phosphoric acids-6-methacryloxy- } \\
\text { hexylesters, diurethane dimethacrylate, TMPTMA, ethyl }\end{array}$ & $\begin{array}{l}\text { 3) Scrub liquid B into the entire wetted surface of the bonding area. The red } \\
\text { color will disappear quickly, indicating that the etching components have } \\
\text { been activated. Continue scrubbing with moderate finger pressure for } 20 \mathrm{~s} \text {. } \\
\text { 4) Air dry thoroughly for } 10 \mathrm{~s} \text { to evaporate water. }\end{array}$ \\
\hline 4-dimethyl aminobenzoate, DL-camphorquinone. & $\begin{array}{l}\text { 5) Apply a second coat of liquid B to the entire bonding surface. Lightly } \\
\text { air thin adhesive layer to adjust film thickness/consistency. } \\
\text { 6) Light cure for } 10 \mathrm{~s} \text {. }\end{array}$ \\
\hline
\end{tabular}

*Manufacturer's information. HEMA, 2-hydroxyethyl methacrylate; TEGDMA, triethylene glycol dimethacrylate; TMPTMA, trimethylolpropane trimethacrylate. Note: The brand name of Adper Scotchbond SE in some countries is Adper SE Plus. 
into disc-pairs using a flowable composite (Filtek Flow; 3M ESPE) light-cured (Elipar Freelight 2) for $160 \mathrm{~s}$ in four different directions, similar to the sandwich technique first described by Inokoshi et al. (12). Next, the sandwiches were sectioned to expose the resin-dentin interface and then processed according to the procedures outlined by Vaz et al. (13) for scanning electron microscopy (SEM) analysis, operating at $20 \mathrm{kV}$.

\section{Results}

\section{Microtensile Bond Strength}

Mean bond strength values are summarized in Table 2 . The independent effects of both main factors (treatment and storage time) on bond strength were not significant $(p=0.18$ and $p=0.29$, respectively). The cross-interaction effect of both factors on bond strength was also found not to be significant $(p=0.59)$.

\section{Failure Mode Analysis}

The failure pattern distribution (\%) is exhibited in Figure 1. Types II and III failure modes were predominant in both the control and the experimental groups, regardless of storage time. Representative SEM micrographs of predominant failure modes are presented in Figure 2.

\section{Bonding Interface}

SEM micrographs of the resin-dentin interfaces from both the control and the experimental groups showed
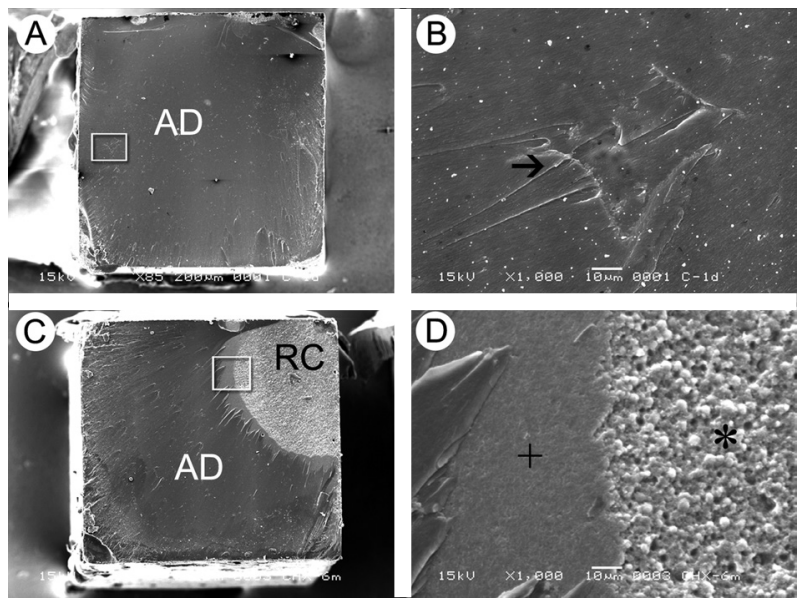

Figure 2. Representative SEM images of the fractured specimens. A: Type 11 failure mode of specimen of the control group that was stored for 1 day. B: Higher magnification of the area limited by a rectangle in image "a" showing the groove pattern of cohesive failure within the adhesive $(\rightarrow)$. C: Type 111 failure mode in specimen of the experimental group that was stored for 6 months. D: Higher magnification of the area limited by a rectangle in image "C", showing a darker and more homogeneous zone that represents cohesive failure within the adhesive resin $(+)$ and a typical granular aspect of cohesive failure within the resin composite $(*)$. AD: adhesive resin. RC: resin composite. similar micromorphological aspects (Fig. 3), exhibiting thin hybrid layers (less than $1.0 \mu \mathrm{m}$ ) and resin tags with lateral branches.

\section{Discussion}

In the present study, the replacement of liquid A of Adper Scotchbond SE by $2 \%$ CHX did not affect the immediate

Table 2. Mean bond strength in MPa (standard deviation) after different storage times

\begin{tabular}{lccc}
\hline \multirow{3}{*}{ Treatment } & \multicolumn{3}{c}{ Storage time } \\
\cline { 2 - 4 } & 1 day & 3 months & 6 months \\
\hline Control & $46.43(11.46)^{\mathrm{A}}$ & $50.02(13.84)^{\mathrm{A}}$ & $45.18(17.92)^{\mathrm{A}}$ \\
Experimental & $37.22(10.45)^{\mathrm{A}}$ & $47.29(12.67)^{\mathrm{A}}$ & $40.22(10.01)^{\mathrm{A}}$ \\
\hline
\end{tabular}

Same letter indicate no statistically significant difference ( $p>0.05)$.

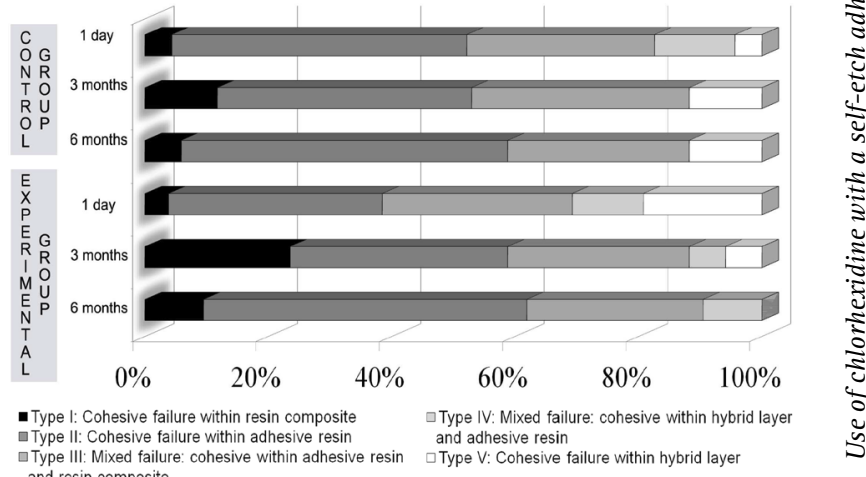

Figure 1. Failure mode distribution (\%).

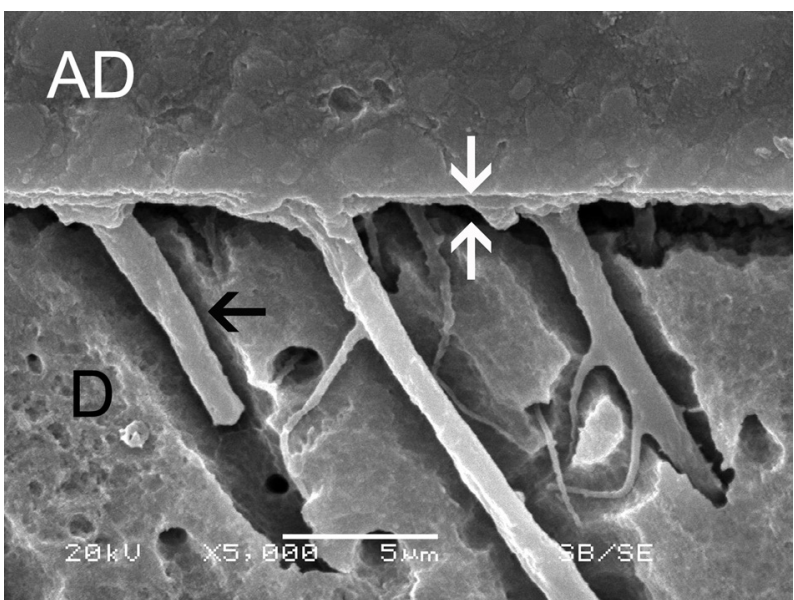

Figure 3. Representative SEM image of the resin-dentin interface from the control group. A thin hybrid layer with less than $1.0 \mu \mathrm{m}$ was created (white arrows). Resin tags with lateral branches could also be identified (black arrow). AD: adhesive resin. 
bond strength ( $p>0.05)$; thus, the first research hypothesis was accepted. The authors believe that interference from water in the bonding performance is minimized using this hybridization protocol, since the effect of $\mathrm{CHX}$ is the focus of the study. The immediate bond strength is most likely preserved because the aqueous solution of $2 \% \mathrm{CHX}$ had a similar ionizing effect as liquid $\mathrm{A}$, which is composed of water and HEMA (approximately $80 \%$ and $20 \%$, respectively). Additionally, there was no evidence of negative interactions between $\mathrm{CHX}$ and the acidic monomers in the liquid B. Actually, previous studies have investigated the incorporation of $\mathrm{CHX}$ into the composition of other dental adhesives, as well as the application of $\mathrm{CHX}$ as a therapeutic primer, demonstrating that there is no significant interference in terms of immediate bond strength to dentin $(14,15)$.

Liquid B of Adper Scotchbond SE is basically composed of acidic monomers, methacrylated co-monomers, and chemically combined fillers in the absence of solvent, giving the material a hydrophobic character (Table 1). Previous studies demonstrate that solvent-free hydrophobic mechanical properties, and enhanced resistance to degradation (16). Another relevant aspect is the continuous scrubbing of liquid B with moderate pressure against the dentin surface, which may have contributed to a better and more homogeneous hybridization (17). In addition, airdrying for $10 \mathrm{~s}$ to evaporate water and further application of the hydrophobic liquid B seems to improve the adhesive performance of SEAs (18). The role of HEMA in liquid A remains unclear from the results of the present study, since the $\mathrm{CHX}$ aqueous solution performed similarly. The authors assume that HEMA in liquid $A$ is not necessary to dissolve monomers in water and prevent phase separation; probably, di-HEMA phosphates in liquid B carried out this function. Indeed, it was demonstrated that the influence of HEMA on bond strength to dentin is material-dependent (19). Another speculation in attempting to better understand the results is related to specific properties of $\mathrm{CHX}$, which presents an amphipathic character at high concentrations that may have favored the resin infiltration in the dentin during hybridization (20). However, this last characteristic requires further investigation in future studies.

The inhibitory effect of MMPs by $\mathrm{CHX}$, which thus improves long-term resin-dentin bonding stability, has been described in previous studies $(1,2,6)$. In the present study, there was no decrease in bond strength after 3 and 6 months of water storage, regardless of the treatment group ( $p>0.05$ ). Thus, as replacing liquid $A$ by $2 \% \mathrm{CHX}$ preserved bond strength after 3 and 6 months, the second hypothesis was accepted. Furthermore, the predominant failure modes were not modified (Figs. 1 and 2). Nevertheless, such adhesion stability cannot be attributed exclusively to CHX. Recently, De Munck et al. $(15,20)$ found enzymatic bond degradation to be minimized by the use of mild SEAs. While released and activated MMPs are active for only a few hours, the degradation effect in resin-dentin bonds created with mild SEAs is most prominent between 6 and 12 months of storage. The amount of MMPs released by mild SEAs is below the picogram sensitivity of the zymographic test; additionally, this low quantity of released enzymes can be de-activated by the SEA itself $(15,20)$. This finding agrees with the results of the present study, since there was no bond strength reduction in either the control or the experimental group after 6 months of water storage. It is also worth noting that despite the fact that the $\mathrm{pH}$ of Adper Scotchbond SE is $<1$ (considered a strong SEA) (21), the acidic reaction initiates with the mixture of both liquid components $A$ and $B$ in cavity preparation. Thus, the concentration of acidic functional monomers (pKa of functional groups) and short mixture time are probably factors that can contribute to a superficial demineralization, simulating a mild SEA behavior. SEM evaluation of the resindentin interfaces of both the control and the experimental groups (Fig. 3) revealed a hybrid layer less than $1.0 \mu \mathrm{m}$, resembling those produced by mild SEAs (22).

It is also important to consider the aging protocol used for bonded specimens, especially regarding the frequency with which the storage solutions were changed. When specimens are stored in water, sorption by the adhesive results in the swelling and softening of the polymeric network, reducing frictional forces between polymeric chains - a phenomenon known as plasticization (23). Swelling facilitates the process by which unreacted monomers trapped in the polymeric network are released into the storage solution. This condition saturates the storage solution, creating a dynamic equilibrium between any undissolved solute and the solution (24). Thus, degradation produced by the solubility of unreacted monomers can be arrested or slowed (24). In the present study, the water was not changed during storage periods. This factor may have contributed to the bond strength stability observed, as the hydrophobicity of Adper Scotchbond SE makes the adhesive region more resistant to degradation, since the polarity of monomers is positively related to water sorption, solubility and decrease of mechanical properties $(4,16)$. Longer periods of water storage, higher frequencies of change of solution, and/or other aging methods may be used in future studies evaluating the bonding stability of SEAs, especially when examining SEAs with such promising bonding performance and using innovative concepts to improve bonding to dentin (25).

Based on the results of the present study, it may be concluded that dentin pre-treatment with a $2 \% \mathrm{CHX}$ 
solution did not influence significantly the immediate bond strength of Adper Scotchbond SE and preservation of bonding was observed after 3 and 6 months.

\section{Resumo}

0 objetivo deste estudo foi o de avaliar o efeito da substituição de um componente do adesivo autocondicionante Adper Scotchbond SE (líquido $\mathrm{A}+$ líquido $\mathrm{B})$ por clorexidina $(\mathrm{CHX})$ a $2 \%$ na resistência da união à dentina após 1 dia, 3 meses ou 6 meses de armazenamento em água. Oito dentes humanos foram seccionados para expor uma superficie plana de dentina e, em seguida, foram aleatoriamente divididos em dois grupos. No grupo controle, as superficies de dentina foram tratadas com o adesivo de acordo com as instruções do fabricante. No grupo experimental, o líquido $\mathrm{A}$ foi substituído por $\mathrm{CHX}$ a $2 \%$. Em seguida, um bloco de resina composta com $6 \mathrm{~mm}$ de altura foi construido sobre a superfície de união. Os dentes restaurados foram então seccionados para produzir espécimes em forma de palito (área transversal $-0,8 \mathrm{~mm}^{2}$ ). A resistência da união à microtração $(\mu \mathrm{T})$ foi mensurada e os padrões de fratura avaliados. Os dados foram analisados por meio de teste de ANOVA dois critérios de medidas repetidas $(\alpha=0,05)$. Quatro dentes adicionais foram processados a fim de realizar uma análise micromorfológica da interface resina-dentina. Os valores de $\mu \top$ não diminuiram significativamente após armazenamento em água em ambos os grupos controle e experimental, cujos valores não diferiram significativamente entre si independentemente do tempo de armazenamento. 0 aspecto morfológico da interface adesiva parece não ter sido afetado pela CHX. Uma maior incidência de falhas coesivas no adesivo e falhas mistas (coesivas no adesivo e na resina composta) foi observada em ambos os grupos. Pode-se concluir que o pré-tratamento da dentina com $\mathrm{CHX}$ a $2 \%$ não influenciou significativamente o desempenho do adesivo avaliado.

\section{Acknowledgments}

This study was supported, in part, by grants from CNPq (\#3307540/200906).

\section{References}

1. Verma R, Singh UP, Tyagi SP, Nagpal R, Manuja N. Long-term bonding effectiveness of simplified etch-and-rinse adhesives to dentin after different surface pre-treatments. J Conserv Dent 2013;16:367-370.

2. Carrilho MR, Geraldeli S, Tay F, de Goes MF, Carvalho RM, Tjaderhane L, et al.. In vivo preservation of the hybrid layer by chlorhexidine. J Dent Res 2007;86:529-533.

3. Ito $S$, Hoshino T, lijima M, Tsukamoto N, Pashley DH, Saito T. Water sorption/solubility of self-etching dentin bonding agents. Dent Mater 2010;26:617-626.

4. Hosaka K, Nakajima M, Takahashi M, Itoh S, Ikeda M, Tagami J, et al.. Relationship between mechanical properties of one-step self-etch adhesives and water sorption. Dent Mater 2010;26:360-367.

5. Hashimoto M. A review--micromorphological evidence of degradation in resin-dentin bonds and potential preventional solutions. J Biomed Mater Res B Appl Biomater 2010;92:268-280.

6. Hebling J, Pashley DH, Tjaderhane L, Tay FR. Chlorhexidine arrests subclinical degradation of dentin hybrid layers in vivo. J Dent Res 2005;84:741-746.

7. Van Meerbeek B, Yoshihara K, Yoshida Y, Mine A, De Munck J, Van Landuyt KL. State of the art of self-etch adhesives. Dent Mater 2011:27:17-28.

8. Van Landuyt KL, Snauwaert J, De Munck J, Peumans M, Yoshida Y,
Poitevin $A$, et al.. Systematic review of the chemical composition of contemporary dental adhesives. Biomaterials 2007;28:3757-3785.

9. Tay FR, King NM, Chan KM, Pashley DH. How can nanoleakage occur in self-etching adhesive systems that demineralize and infiltrate simultaneously? J Adhes Dent 2002;4:255-269.

10. Carvalho RM, Chersoni S, Frankenberger R, Pashley DH, Prati C, Tay FR. A challenge to the conventional wisdom that simultaneous etching and resin infiltration always occurs in self-etch adhesives. Biomaterials 2005;26:1035-1042.

11. Salz U, Zimmermann J, Zeuner F, Moszner N. Hydrolytic stability of self-etching adhesive systems. J Adhes Dent 2005;7:107-116.

12. Inokoshi $S$, Hosoda $H$, Harnirattisai $C$, Shimada $Y$. Interfacial structure between dentin and seven dentin bonding systems revealed using argon ion beam etching. Oper Dent 1993;18:8-16.

13. Vaz RR, Hipolito VD, D'Alpino PH, Goes MF. Bond strength and interfacial micromorphology of etch-and-rinse and self-adhesive resin cements to dentin. J Prosthodont 2012;21:101-111.

14. Lenzi $T L$, Tedesco TK, Soares FZ, Loguercio AD, Rocha Rde 0 . Chlorhexidine does not increase immediate bond strength of etchand-rinse adhesive to caries-affected dentin of primary and permanent teeth. Braz Dent J 2012;23:438-442.

15. De Munck J, Van den Steen PE, Mine A, Van Landuyt KL, Poitevin A, Opdenakker $\mathrm{G}$, et al.. Inhibition of enzymatic degradation of adhesivedentin interfaces. J Dent Res 2009;88:1101-1106.

16. Yiu CK, King NM, Pashley DH, Suh BI, Carvalho RM, Carrilho MR, et al.. Effect of resin hydrophilicity and water storage on resin strength. Biomaterials 2004;25:5789-5796.

17. do Amaral RC, Stanislawczuk R, Zander-Grande C, Michel MD, Reis A, Loguercio AD. Active application improves the bonding performance of self-etch adhesives to dentin. J Dent 2009;37:82-90.

18. Albuquerque $M$, Pegoraro $M$, Mattei $G$, Reis $A$, Loguercio AD. Effect of double-application or the application of a hydrophobic layer for improved efficacy of one-step self-etch systems in enamel and dentin. Oper Dent 2008;33:564-570.

19. Felizardo KR, Lemos LV, de Carvalho RV, Gonini Junior A, Lopes MB, Moura SK. Bond strength of HEMA-containing versus HEMA-free selfetch adhesive systems to dentin. Braz Dent J 2011;22:468-472.

20. De Munck J, Mine A, Van den Steen PE, Van Landuyt KL, Poitevin A, Opdenakker $G$, et al.. Enzymatic degradation of adhesive-dentin interfaces produced by mild self-etch adhesives. Eur J Oral Sci 2010;118:494-501.

21. Mine A, De Munck J, Cardoso MV, Van Landuyt KL, Poitevin A, Kuboki T, et al.. Bonding effectiveness of two contemporary self-etch adhesives to enamel and dentin. J Dent 2009;37:872-883.

22. Sarr M, Kane AW, Vreven J, Mine A, Van Landuyt KL, Peumans $M$, et al.. Microtensile bond strength and interfacial characterization of 11 contemporary adhesives bonded to bur-cut dentin. Oper Dent 2010;35:94-104.

23. Ferracane JL, Berge $\mathrm{HX}$, Condon JR. In vitro aging of dental composites in water--effect of degree of conversion, filler volume, and filler/ matrix coupling. J Biomed Mater Res 1998;42:465-472.

24. Skovron L, Kogeo D, Gordillo LA, Meier MM, Gomes OM, Reis A, et al.. Effects of immersion time and frequency of water exchange on durability of etch-and-rinse adhesive. J Biomed Mater Res B Appl Biomater 2010;95:339-346.

25. Van Meerbeek B, Peumans M, Poitevin A, Mine A, Van Ende A, Neves A, et al.. Relationship between bond-strength tests and clinical outcomes. Dent Mater 2010;26:e100-e121. 